\title{
Vegetative responses to temperature and photoperiod in saplings of brazilwood (Caesalpinia echinata Lam., Leguminosae)
}

\author{
Josimara N. Rondon, Lilian B.P. Zaidan, Marisa Domingos, Claudio J. Barbedo and Rita de \\ Cássia L. Figueiredo-Ribeiro*
}

Instituto de Botânica, CP 3005, 01061-970 São Paulo, SP, Brazil; *Corresponding author: ritarib@usp.br Received: 09 October 2006; Returned for revision: 28 November 2006; Accepted: 06 February 2007

Caesalpinia echinata Lam. (brazilwood) is an endangered tree species occurring along the eastern coast of Brazil from latitudes $5^{\circ} 56^{\prime} \mathrm{S}$ to $22^{\circ} 56^{\prime} \mathrm{S}$. With such a range of distribution it is expected that temperature and daylength may affect plant development, which was examined in this study. One- and five-year-old saplings were grown under controlled photoperiods of $8 \mathrm{~h}, 12 \mathrm{~h}$ and $20 \mathrm{~h}$, and in a greenhouse under natural light during 16 months. In another experiment, oneyear-old saplings were cultivated for six months in a growth cabinet, with reduced maximum temperature, and in the greenhouse. Leaf number, stem height and stem diameter at the soil surface were evaluated every two months (experiment 1 ) or every month (experiment 2 ). In experiment 1 , no significant effect of photoperiod on growth of saplings was observed. The increase of leaf number with time followed a polynomial model, and the slope of the curves differed significantly for saplings of the two ages. Stem height increased linearly in younger saplings and fitted a polynomial curve in older saplings. Stem diameter enlarged linearly with time in all saplings. Growth parameters were significantly related to high temperatures. In experiment 2, significant regressions between growth and the maximum daily temperatures recorded were also found for increase of leaf number and stem height increment. Our results show that vegetative growth of the saplings of this tropical species is affected by temperature but not by photoperiod.

Key words: Atlantic forest, endangered species, tree growth

Crescimento vegetativo de plantas jovens de pau-brasil (Caesalpinia echinata Lam., Leguminosae) em resposta à temperatura e ao fotoperíodo: Caesalpinia echinata Lam. (pau-brasil) é uma espécie arbórea ameaçada, que ocorre na costa leste do Brasil, em latitudes de $5^{\circ} 56^{\prime} \mathrm{S}$ a $22^{\circ} 56^{\prime} \mathrm{S}$. Em tal faixa de distribuição espera-se que a temperatura e $o$ comprimento do dia possam afetar o desenvolvimento da planta, o que foi investigado no presente estudo. Plantas jovens com um e cinco anos de idade foram cultivadas sob fotoperíodos controlados de $8 \mathrm{~h}, 12 \mathrm{~h}$ e $20 \mathrm{~h}$ e em casa de vegetação, sob luz natural, durante 16 meses. Em outro experimento, plantas jovens com um ano de idade foram cultivadas por seis meses em câmara de crescimento, onde a temperatura máxima foi reduzida, e em casa de vegetação. O número de folhas, a altura do caule e o diâmetro do caule à superfície do solo foram avaliados a cada dois meses (experimento 1), ou mensalmente (experimento 2). No experimento 1, não foi encontrada alteração de crescimento nas plantas crescendo sob os diferentes tratamentos fotoperiódicos. Foi possível ajustar regressão polinomial para o aumento do número de folhas, em função do tempo, com diferença significativa na inclinação da curva para as plantas das duas idades. A altura do caule aumentou linearmente nas plantas mais jovens e, nas mais velhas, tal parâmetro ajustou-se à regressão polinomial. As medidas de crescimento relacionaram-se significativamente com as médias das temperaturas máximas diárias registradas. No experimento 2 , também foram encontradas regressões significativas entre o crescimento das plantas e as temperaturas máximas para aumento do número de folhas e da altura do caule. Os resultados mostraram que o crescimento vegetativo dessa espécie tropical é afetado pela temperatura e não pelo fotoperíodo.

Palavras-chave: crescimento de árvores, espécie ameaçada, Mata Atlântica, pau-brasil

Braz. J. Plant Physiol, 18(4):467-474, 2006 


\section{INTRODUCTION}

A strategy that can facilitate the maintenance or the recovery of biodiversity is the establishment of native forest plantations when appropriated lands are available. These might be considered as an option for mitigating deforestation, since forest plantations can provide products that otherwise would be taken from natural forests (Montagnini, 2001). Caesalpinia echinata Lam. (brazilwood) is a tree species native to the Atlantic Forest. The species was abundant along the seacoast of the northeastern and southeastern regions of Brazil (Rocha, 2004), mainly in three major areas of dry seasonal forests separated by regions of humid vegetation (Lewis, 1998; Cardoso et al., 2005 and references therein). The species was overexploited at the beginning of the colonization period ( $16^{\text {th }}$ to $18^{\text {th }}$ centuries) due to the interest in the red dye produced by the trees. This exploitation and the general reduction of the Atlantic Forest due to deforestation restricted the natural distribution of the species, and it is now considered as an endangered species (IBAMA, 1992). Nowadays, the wood is used in Brazil and exported to other countries for the manufacture of high quality bows of string instruments. Studies on the genetic variability of brazilwood indicated a high level of differentiation in five natural populations in Southeast Brazil (Cardoso et al., 1998). More recently, Cardoso et al. (2005) suggested that fragmentation of populations of $C$. echinata has led to an increase in genetic differentiation between fragments, emphasizing the relevance of investigating the performance of the species in different environments.

Environmental variables including light regimes and temperature affect development of many important crops such as wheat, rice, potato, soybean, fruits and ornamental plants from temperate regions (Lafta and Lorenzen, 1995; Myster and Moe, 1995; Robert et al., 1999; Zheng et al., 2002; Hendrickson et al., 2004; Richardson et al., 2004). However, studies relating the effects of daylength and temperature on plant growth are still scarce for tropical species (Vaz et al., 2004), if one considers the plant diversity in these areas. Concerning tropical trees, a long term study of six species of an old-growth tropical rain forest relating productivity, atmospheric carbon dynamics and annual temperatures was conducted by Clark et al. (2003), in Costa Rica. The authors concluded that the annual increments in tree diameter were negatively correlated with annual means of daily minimum temperatures and that net primary production covaried negatively with inferred annual net $\mathrm{CO}_{2}$ exchange between the terrestrial tropics and the atmosphere. Stubblebine et al. (1978) and Souza et al. (1996) analyzed the vegetative growth of the tree species, Hymenaea courbaril L. and Mimosa scabrella Benth, focusing on photoperiodic control. The authors concluded that both species were sensitive to long photoperiods, presenting greater stem length than plants under short-days. Paulilo and Felippe (1998) revised the available data for tree- and shrub-species from the Cerrado and the Atlantic Forest and mentioned similar photoperiodic effects on their growth.

More recently, photoperiodic control of tropical tree development was studied by Borchert et al. (2005). Mean times of synchronous flowering in 41 representative tree species observed in seven tropical forests ranging from $10^{\circ} \mathrm{N}$ to $16^{\circ} \mathrm{S}$ were analyzed. According to the authors, photoperiodic control of vegetative development and flowering in tropical trees evolved in response to different adaptive pressures. This study confirmed for the first time that synchronous flowering in rainforest tree species near the Equator is related to a timing mechanism.

Brazilwood occurs along the eastern coast of the country from latitudes $5^{\circ} 56^{\prime} \mathrm{S}$ to $22^{\circ} 56^{\prime} \mathrm{S}$, in a number of edaphic conditions (Rocha, 2004). In this latitudinal range, daylength varies from $10.47 \mathrm{~h}$ to $13.29 \mathrm{~h}$ and the average minimum and maximum temperatures may oscillate from $18.2^{\circ} \mathrm{C}$ to $30.2^{\circ} \mathrm{C}$ during the year (Funari, 1983). With such a range of environmental conditions, it might be expected that temperature and daylength would affect the development of plants of $C$. echinata. The aim of the present work was to analyze vegetative responses of saplings of this species growing experimentally under different photoperiods and temperature conditions.

\section{MATERIAL AND METHODS}

Two experiments (named experiments 1 and 2) were carried out independently in a greenhouse at the Instituto de Botânica, São Paulo (2338'25.4” S, 46³7'19.4” W). Seeds were collected from a 23 -year-old plantation of Caesalpinia echinata in Moji-Guaçu (2235' S, 4744' W), São Paulo State, Brazil. This plantation was originated from seeds collected in the natural area of 
brazilwood distribution, in Northeast Brazil and proved to have a high genetic variability (Giudice-Neto et al., 2005). After germination the seedlings were kept in $15 \mathrm{~cm}$ long tubular pots under artificial shade (40\%) imposed by a neutral screen.

In experiment 1 , to test the effect of photoperiod on vegetative growth and flowering, one- and five-year-old saplings were used. The saplings were transferred to pots with 2 and 5 L capacity, respectively, containing a mixture of ground Pinus bark, peat, vermiculite and sand (4:3:2:1 v/v), according to Aguiar et al. (1997), modified by S. Kanashiro (personal communication). Ten saplings of each age were maintained in the greenhouse (natural photoperiod) throughout the experimental period. Other three sets of 10 saplings of each age were respectively submitted to controlled photoperiods of $8 \mathrm{~h}, 12 \mathrm{~h}$ and 20 h. From $0900 \mathrm{~h}$ to $1700 \mathrm{~h}$, saplings of these treatments were exposed to $8 \mathrm{~h}$ of natural light in the greenhouse and then transferred to individual dark chambers $\left(6.75 \mathrm{~m}^{3}\right)$, where saplings from treatments $8 \mathrm{~h}, 12 \mathrm{~h}$ and $20 \mathrm{~h}$ received supplementary low irradiance light (7-10 $\mu \mathrm{mol} \mathrm{m}^{-2} \mathrm{~s}^{-1}$ of total photon flux radiance at plant level) during 0,4 and $12 \mathrm{~h}$, respectively, appropriate to stimulate photomorphogenic responses involving the phytochrome system. This additional light was furnished by OsramUniversal Daylight Special - 40W, and General Electric Tungsten - 100W lamps. Automatic clocks (type WA1z30.1, Switzerland) controlled the operation of the lamps in order to give the required light period. Photosynthetic active radiation (PAR) inside the greenhouse was $300-800 \mu \mathrm{mol} \mathrm{m} \mathrm{m}^{-2} \mathrm{~s}^{-1}$. Saplings received $150 \mathrm{~mL}$ (one-year-old saplings) and $450 \mathrm{~mL}$ (five-year-old saplings) of N-P-K (10:30:20) liquid fertilizer $\left(1 \mathrm{~g} \mathrm{~L}^{-1}\right)$ twice each week. Pots were irrigated daily with water at $0900 \mathrm{~h}$ to $1600 \mathrm{~h}$. Measurements of stem height, leaf number and stem diameter at soil surface level (DSL) - using a digital pachymeter (Mitutoyo, Japan) - were evaluated every two months, from May 2001 to September 2002.

Growth variables of saplings in this experiment were compared by a multiway factorial analysis of variance, adopting a repeated-measurements experimental design according to Zar (1999). The growth measurement of the saplings along time was considered one among-subjects factor and photoperiod and age of saplings were considered two within-subjects factors. The growth data were left untransformed as they presented normal distribution and equal variances. When factorial analysis of variance indicated significant differences, the mean values were compared by Tukey test $(P<0.05)$. Regression analyses were used to test the variations along time.

In experiment 2, 10 one-year-old saplings were cultivated as described above and kept under natural temperature and photoperiod in the greenhouse. Ten additional saplings were maintained in a glass compartment (growth cabinet) inside the same greenhouse, thus subjected to the same photoperiod, but with temperature reduced by air conditioning. Measurements of stem height, leaf number and stem diameter at DSL were evaluated monthly from March to July 2003.

Growth variables of saplings in this experiment were also compared by a repeated-measurements experimental design (Zar, 1999). The growth measurement of the saplings along time was considered one among-subjects factor and experimental environments a within-subject factor. The growth data were left untransformed as they presented normal distribution and equal variances. When applicable, the mean values were compared by Tukey test $(P<0.05)$. Regression analyses were also used to test the variations along time.

Maximum and minimum daily temperatures in all experimental environments were recorded with maximum and minimum thermometers and monthly means were calculated. The temperatures ranged from $11.0^{\circ} \mathrm{C}$ to $37.6^{\circ} \mathrm{C}$ in the greenhouse and from $11.7^{\circ} \mathrm{C}$ to $26.4^{\circ} \mathrm{C}$ in the photoperiodic chambers (experiment 1 ), and from $13.0^{\circ} \mathrm{C}$ to $33.8^{\circ} \mathrm{C}$ in the greenhouse and from $13.9^{\circ} \mathrm{C}$ to $27.8^{\circ} \mathrm{C}$ in the growth cabinet (experiment 2) (Figure 1).

Regression analyses were performed to test the relationship between growth measurements (taken bimonthly in experiment 1 or monthly in experiment 2) and means of daily maximum temperatures. In experiment 2 , maximum temperature was the only variable effectively managed inside the growth cabinet.

\section{RESULTS}

The typical sigmoid pattern of growth (leaf number and stem height) was observed for one- and five-year-old saplings growing under different photoperiods throughout the experimental period (16 months), from May 2001 to September 2002 (Experiment 1; Figure 2). As 


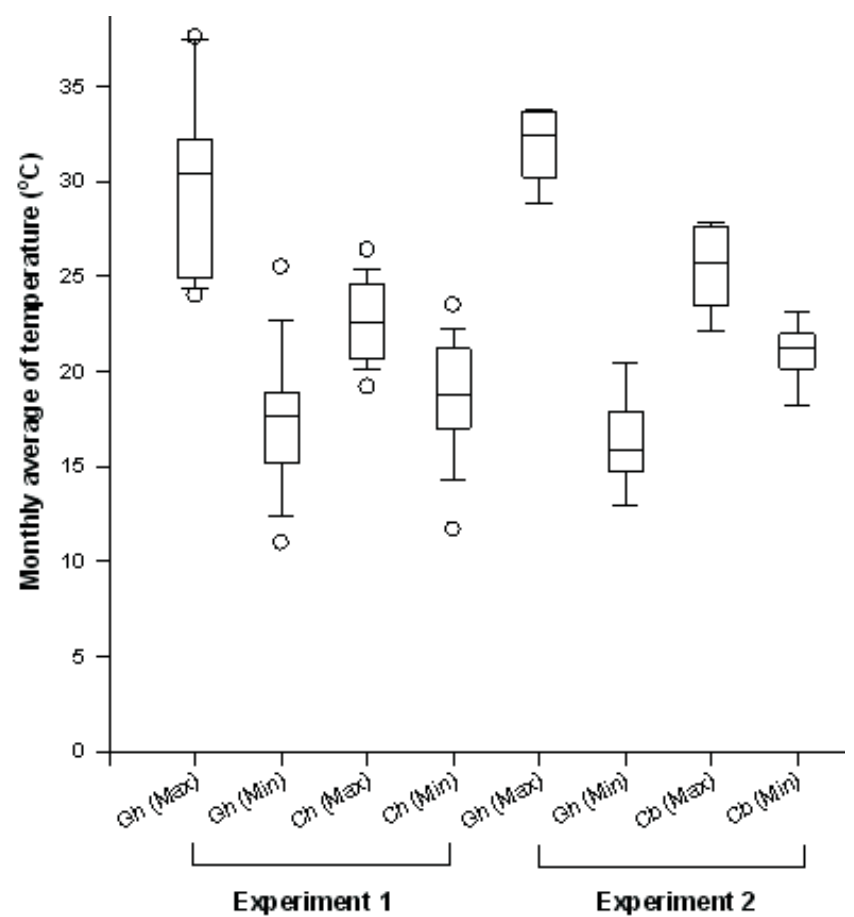

Figure 1. Boxplot representation of monthly means of daily maximum (Max) and minimum (Min) temperatures from May 2001 to October 2002 (Experiment 1) in the greenhouse (Gh), to which all saplings were exposed from $0900 \mathrm{~h}$ to $1700 \mathrm{~h}$, and in the photoperiodic chambers $(\mathrm{Ch})$, to which saplings were exposed for complementary light treatments, and from March to July 2003 (Experiment 2) in the greenhouse $(\mathrm{Gh})$ and in the growth cabinet $(\mathrm{Cb})$. Boxes indicate from $25^{\text {th }}$ to $75^{\text {th }}$ percentiles, horizontal lines in the boxes the $50^{\text {th }}$ percentile, error bars the $10^{\text {th }}$ to $90^{\text {th }}$ percentiles and symbols $(O)$ the $5^{\text {th }}$ and $95^{\text {th }}$ percentiles.

expected, older saplings had significantly more leaves and produced taller stems with larger diameters than the younger individuals.

The factorial analyses of variance indicated that significant interactions were only detected between the age of saplings and time for number of leaves and stem height. The growth pattern concerning number of leaves of both one- and five-year-old saplings followed a third degree polynomial model, but the slope of the curves differed significantly (Figure 2A). However, while the stem height increased linearly in younger saplings, it fitted to a third degree polynomial curve in older saplings (Figure 2B). The diameter of the stem at DSL increased linearly with time in saplings of both ages (Figure 2C). Growth measurements were significantly enhanced from
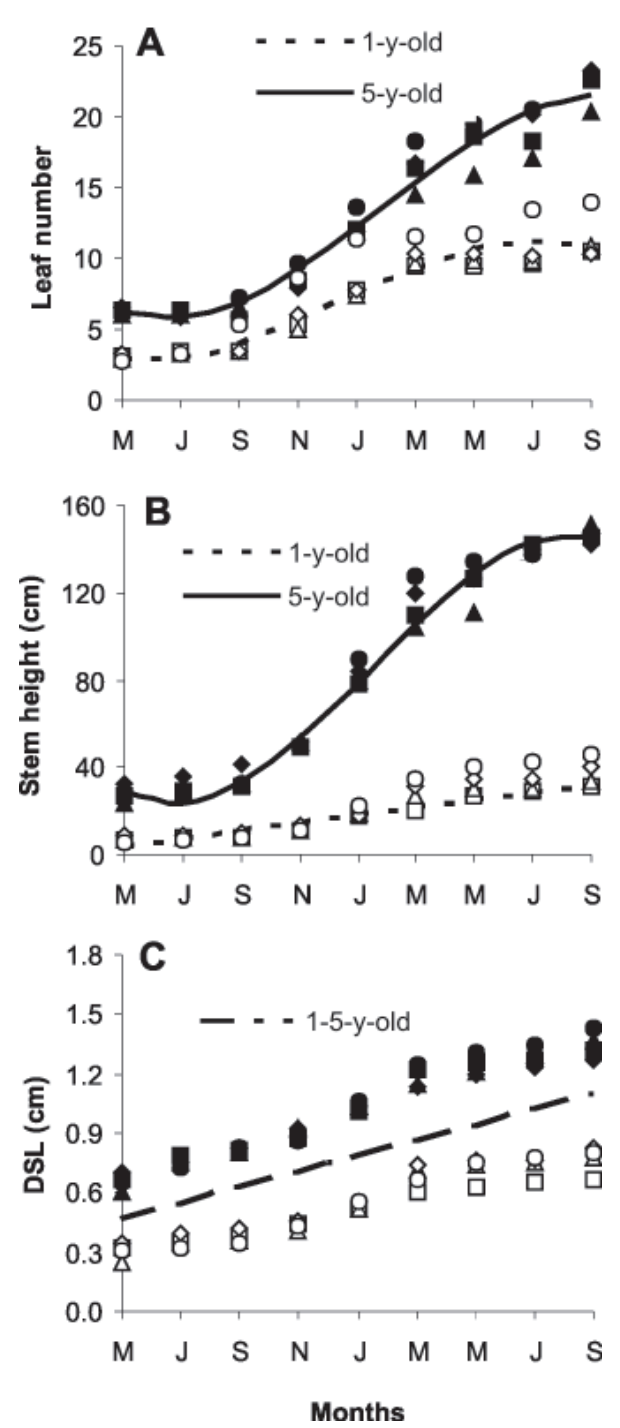

Figure 2. Growth measurements (leaf number (A), stem height (B) and stem diameter at soil surface level - DSL (C)) of one-year-old (open symbols) and five-year-old (closed symbols) saplings of $C$. echinata growing under $8 \mathrm{~h}(\mathrm{O}-\bullet)$,

$12 \mathrm{~h}(\Delta-\mathbf{\Delta}), 20 \mathrm{~h}(\square-\boldsymbol{-})$ and natural $(\diamond-\diamond)$ photoperiods during 16 months $(n=10)$. Regression equations: $\mathrm{Y}_{(\mathrm{A}, 1-\mathrm{y} \text {-old })}=$ $6.2-0.7 \mathrm{x}+0.2 \mathrm{x}^{2}-0.009 \mathrm{x}^{3}\left(r^{2}=0.87\right), \mathrm{Y}_{(\mathrm{A}, 5 \text {-y-old })}=2.9-0.2 \mathrm{x}+0.2 \mathrm{x}^{2}-$ $0.007 \mathrm{x}^{3}\left(r^{2}=0.96\right)[\mathrm{CV}=23 \%] ; \mathrm{Y}_{(\mathrm{B}, 1-\mathrm{y} \text {-old })}=3.7+1.7 \mathrm{x}\left(r^{2}=0.86\right)$, $\mathrm{Y}_{(\mathrm{B}, 5 \text {-y-old })}=29.3-7.1 \mathrm{x}+2.4 \mathrm{x}^{2}-0.09 \mathrm{x}^{3}\left(r^{2}=0.95\right)[\mathrm{CV}=8 \%]$ $\mathrm{Y}_{(\mathrm{C}, 1-5-\mathrm{y}-\mathrm{old})}^{(\mathrm{B}, 5-\mathrm{y} \text {-ld })}=0.49+0.04 \mathrm{x}\left(r^{2}=0.40\right)[\mathrm{CV}=17 \%]$.

September 2001 to May 2002, as could be deduced from the regression equations.

As photoperiod did not affect significantly the growth of both one- and five-year-old saplings and all the saplings were maintained in the same environment during the natural daylight period and thus subjected to the 
same variation of temperature, the data of one- and fiveyear-old saplings from all photoperiodic treatments $(8 \mathrm{~h}$, $12 \mathrm{~h}, 20 \mathrm{~h}$ and natural) were plotted together against bimonthly means of maximum daily temperatures in the greenhouse. Independently of the age of the saplings, third degree polynomial equations explained the relationships between growth variables and maximum temperatures (Figure 3A, B, C). The most favorable temperature range seemed to be from 30 to nearly $37^{\circ} \mathrm{C}$ concerning leaf number and stem height, whilst the growth in stem diameter increased from approximately $35^{\circ} \mathrm{C}$ on.

The pattern of development of saplings growing both in the glasshouse and in the growth cabinet was significantly different. As a consequence, the factorial analyses of variance identified significant interactions between the two environments and time for all parameters. Leaf number, stem height and stem diameter in saplings growing in both environments increased linearly with time, but reached higher values in the plants growing in the greenhouse than those in the growth cabinet, as shown by the different slopes of the curves (Experiment 2; Figure 4A, B, C).

The increases of leaf number and stem height in oneyear-old saplings growing both in the greenhouse and in the growth cabinet were significantly related to maximum daily temperatures during the experimental period. Maximum growth increment in terms of leaf number was reached at nearly $30^{\circ} \mathrm{C}$. These relations fitted to third degree and linear regressions, respectively (Figure 5A, B). The increment in stem diameter was not associated with temperature during the experimental period (Figure $5 C)$.

\section{DISCUSSION}

Brazilwood is distributed along the eastern coast of Brazil, from Rio Grande do Norte State to Rio de Janeiro State, in a range of environmental conditions, including daylength and a high average of minimum and maximum temperatures (Funari, 1983). Although these ranges are not so wide when compared to those found at higher latitudes, we assumed that such variations could affect the development of the tropical tree C. echinata. However, data presented here show that temperature but not photoperiod affected growth of this tropical species.
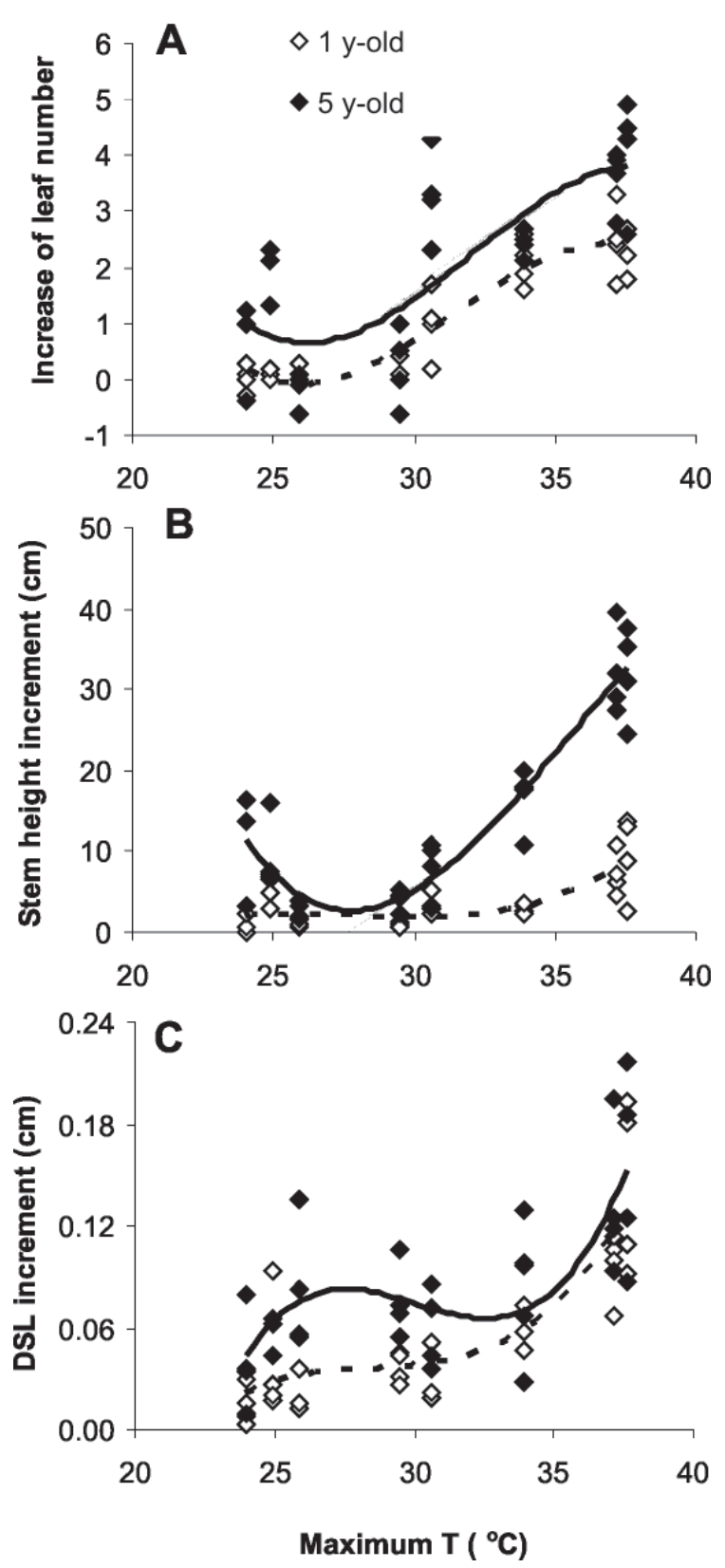

Figure 3. Relationships between bimonthly increase of leaf number (A), stem height (B), and stem diameter at soil surface level - DSL (C) increments in one-year-old and five-year-old saplings of C. echinata, growing under $8 \mathrm{~h}$, $12 \mathrm{~h}, 20 \mathrm{~h}$ and natural photoperiodic conditions, and daily maximum temperatures $(n=32)$. Regression equations $(P$ $<0.001): \mathrm{Y}_{(\mathrm{A}, 1-\mathrm{y}-\mathrm{old})}=112.2-11.3 \mathrm{X}+0.4 \mathrm{x}^{2}-0.004 \mathrm{x}^{3}\left(r^{2}=0.87\right)$, $\mathrm{Y}_{(\mathrm{A}, \text { 5-y-old })}=118.8-11.7 \mathrm{x}+0.4 \mathrm{x}^{2}-0.004 \mathrm{x}^{3}\left(r^{2}=0.60\right) ; \mathrm{Y}_{(\mathrm{B}, 1-\mathrm{y}-\mathrm{-old})}=$ $-190.3+20.9 \mathrm{X}-0.7 \mathrm{x}^{2}+0.009 \mathrm{x}^{3}\left(r^{2}=0.59\right) ; \mathrm{Y}_{(\mathrm{B}, 5 \text { - } \mathrm{y} \text {-old })}=926.3-$ $84.8 \mathrm{x}+2.5 \mathrm{x}^{2}-0.024 \mathrm{x}^{3}\left(r^{2}=0.89\right) ; \mathrm{Y}_{(\mathrm{C}, 1-\mathrm{y}-\mathrm{old})}=-2.7+0.3 \mathrm{x}-$ $0.01 \mathrm{x}^{2}+0.0001 \mathrm{x}^{3}\left(r^{2}=0.70\right) ; \mathrm{Y}_{(\mathrm{C}, 5 \text { - } \mathrm{y} \text {-old })}=-7.2+0.7 \mathrm{x}-$ $0.02 \mathrm{x}^{2}+0.0003 \mathrm{x}^{3}\left(r^{2}=0.55\right)$. 

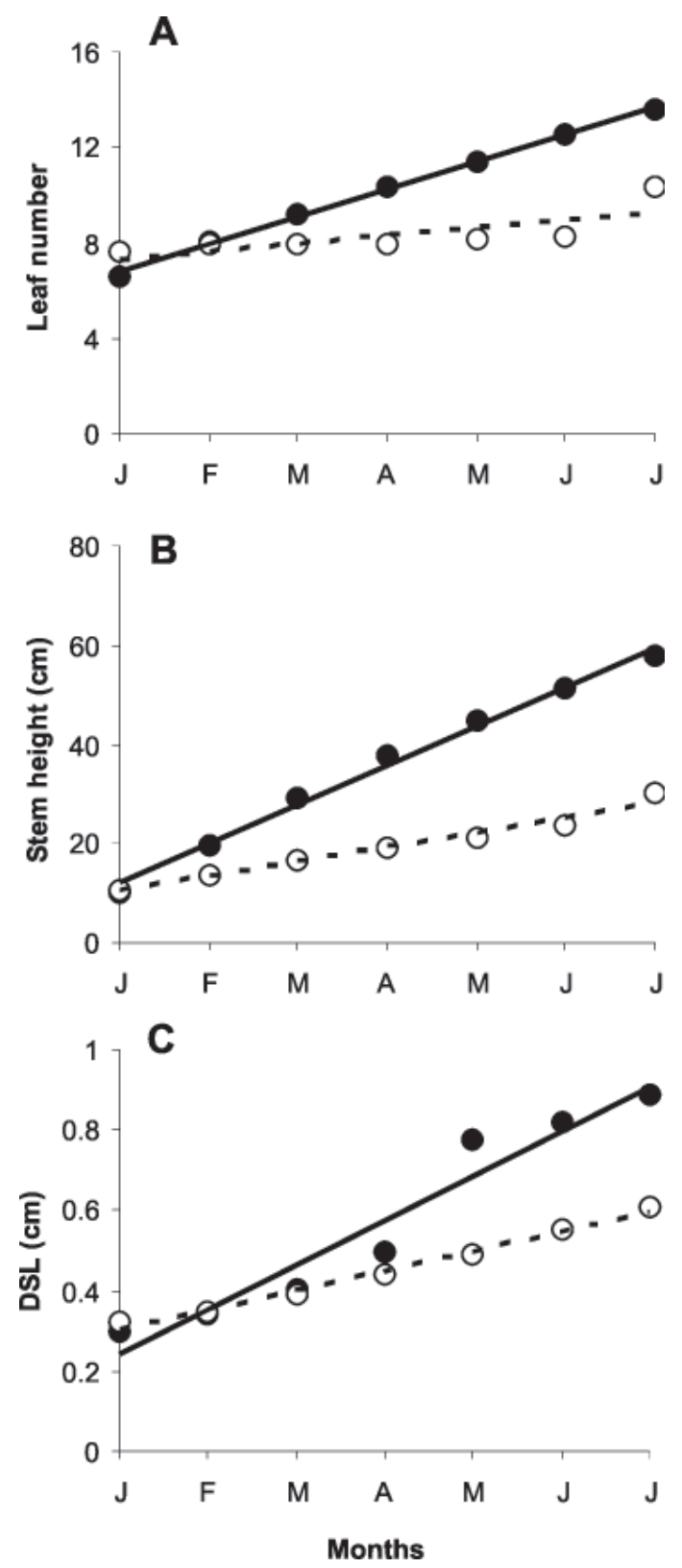

Figure 4. Growth in leaf number (A), stem height (B), and stem diameter at soil surface level - DSL (C) of one-yearold saplings of $C$. echinata in the greenhouse ( $)$ and in the growth cabinet (o) during 6 months $(n=10)$. Regression equations: $\mathrm{Y}_{(\mathrm{A}, \mathrm{Gh})}=6.8+1.2 \mathrm{x}\left(r^{2}=0.99\right), \mathrm{Y}_{(\mathrm{A}, \mathrm{Cb})}=7.4+0.3 \times\left(r^{2}\right.$ $=0.59)[\mathrm{CV}=25 \%] ; \mathrm{Y}_{(\mathrm{B}, \mathrm{Gh})}=11.9+7.8 \times\left(r^{2}=0.99\right), \mathrm{Y}_{(\mathrm{B}, \mathrm{Cb})}=$ $10.4+3.0 \mathrm{x}\left(r^{2}=0.97\right)[\mathrm{CV}=29 \%] ; \mathrm{Y}_{(\mathrm{C}, \mathrm{Gh})}=0.24+0.11 \times\left(r^{2}=\right.$ $0.94), \mathrm{Y}_{(\mathrm{C}, \mathrm{Cb})}=0.3+0.05 \times\left(r^{2}=0.99\right)[\mathrm{CV}=13 \%]$.

Regardless of plant age, a longer-term experiment (Experiment 1) showed that the exponential phase of growth coincided with the warmer period of the year
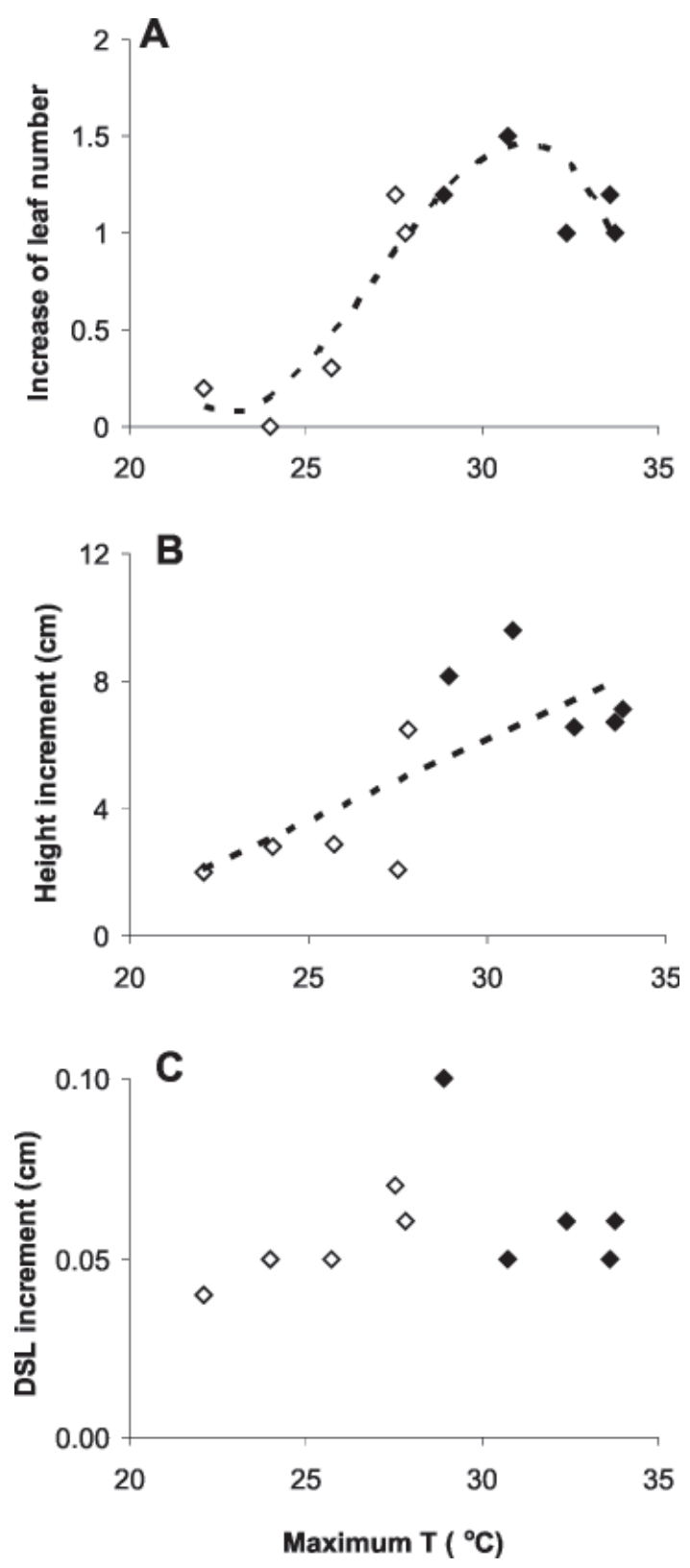

Figure 5. Relationships between monthly increase of leaf number (A), stem height (B), and stem diameter increments at soil surface level - DSL $(\mathbf{C})$ in one-year-old saplings of $C$. echinata growing in the greenhouse $(\diamond)$ and in the growth cabinet $(\diamond)$ and monthly average of maximum daily temperatures $(n=10)$. Regression equations $(P<0.05)$ : $\mathrm{Y}_{\mathrm{A}}$ $=86.6-10.0 \mathrm{x}+0.48 \mathrm{x}^{2}-0.005 \mathrm{x}^{3}\left(r^{2}=0.87\right) ; \mathrm{Y}_{\mathrm{B}}=-9.1+0.5 \mathrm{x}\left(r^{2}=\right.$ $0.55)$.

(Figure 2). This could indicate that temperature can influence the growth of the saplings of this tropical tree. Depending on the growth variable considered, the 
favorable temperature ranges may change. Thus, the suitable temperatures for leaf number and stem height increments seemed to be lower than those for DSL increment. Indeed, the regression analyses (Figure 3) confirmed this hypothesis, although a linear relation was not found, indicating that factors other than temperature, such as relative humidity, acted concurrently to promote plant development during the growth season.

Experiment 2 confirmed the positive association between temperature and growth of saplings of C. echinata, although to a lesser extent. The highest growth occurred in a narrower range of high temperatures since the experiment was performed in the period of the year (March to July) when the effect of higher temperatures would be less evidenced.

In Brazil, minimum mean temperatures around or below $15^{\circ} \mathrm{C}$ are recorded at higher latitudes (Funari, 1983) where this species does not occur naturally (Lewis, 1998), suggesting that $C$. echinata is sensitive to low temperatures.

Although photoperiod may affect vegetative growth as well as other physiological processes such as flowering, tuberization and dormancy of plants (Thomas and VincePrue, 1997), long days (LD) were not effective in promoting growth in one-year and five-year-old saplings of Caesalpinia echinata during the period of analysis. However, vegetative growth responses of the older plants were more pronounced.

The effectiveness of photoperiod in promoting plant growth varies among species (Adams and Langton, 2005). In ornamental plants, for example, the photoperiod impacted the mean dry weight gain of more than $75 \%$ of 41 species, principally those grown under LD (Mattson and Erwin, 2005). However, for five populations of the tropical tree Hymenaea courbaryl, originated from regions between nearly $20^{\circ} \mathrm{N}$ and $2^{\circ} \mathrm{S}, \mathrm{LD}$ affected all the plants similarly, despite their origin. The average stem length of LD plants was twice that of seedlings growing under short days and nearly ceased during winter but resumed in the spring (Stubblebine et al., 1978).

Our results show that saplings of $C$. echinata grew continuously in the greenhouse where irradiance was slightly reduced when compared with full sunlight. Even though rainfall pattern is often considered the most prominent physical factor marking seasonal variations in the tropics (Stubblebine et al., 1978), the growth of tropical species can be also directly influenced by light quantity and quality, with the response varying among species (Souza and Válio, 2003; Válio, 2003) due to exogenous and endogenous factors acting concomitantly (Thomas and Vince-Prue, 1997). Caesalpinia echinata is commonly found inside the forest where there is a reduction in the red:far-red ratio and in the photon flux density, being considered a climax or a late-secondary species (Carvalho, 1994; Cardoso et al., 1998) and shade-tolerant. A study of three legume tree species from a semi-deciduous dry forest within the Atlantic Forest, including $C$. echinata, confirmed this species as a typical shade-tolerant plant (Geßler et al., 2005). Thus the reduction of irradiance in the greenhouse seemed not to be restrictive to the growth of saplings of $C$. echinata.

According to Hendrickson et al. (2004), when other limiting growth conditions are absent, temperature increases can contribute to higher plant productivity and this effect is enhanced when the latitudinal and altitudinal temperature of the species are approached. This could be important to understand plant growth and distribution of species.

Results presented here concerning vegetative responses to temperature and photoperiod provide valuable information on ex situ propagation of $C$. echinata, contributing to the conservation of this endangered species from the Atlantic Forest.

Acknowledgements: This work was supported by the State of São Paulo Research Foundation (FAPESP), Grant 2000/ 06422-4. L.B.P. Zaidan, M. Domingos, R.C.L. Figueiredo-Ribeiro and C.J. Barbedo are researchers associated with CNPq. We are grateful to Dr. Terezinha Paulilo, from the University of Santa Catarina (Brazil), for the critical review of the manuscript. We also thank Dr. Roger L. Mansfield (Astronomical Data Service, Colorado Springs, USA), for calculating the photoperiod values, and Dr. Frederico Funari (Astronomic and Geophysics Institute, University of São Paulo, Brazil), for providing data on temperatures.

\section{REFERENCES}

Adams SR, Langton FA (2005) Photoperiod and plant growth: a review. J. Hort. Sci. Biotech. 80:2-10.

Aguiar FFA, Pinto MM, Giudice Neto JD, Barbedo CJ (1997) Influência da adubação no crescimento de mudas de paubrasil (Caesalpinia echinata Lam.). Rev. Bras. Hort. Ornam. 3:42-49. 
Bartlett GA, Remphrey WR (1998) The effect of reduced quantities of photosynthetically active radiation on Fraxinus pennsylvanica growth and architecture. Can. J. Bot. 76:1359-1365.

Borchet R, Renner SS, Calle Z, Navarrete D, Tye A, Gautier L, Spichiger R, von Hildebrand P (2005) Photoperiodic induction of synchronous flowering near the Equator. Nature 433:627-629.

Cardoso MA, Provant J, Powell W, Ferreira PCG, Oliveira DED (1998) High genetic differentiation among remnant populations of the endangered Caesalpinia echinata Lam. (Leguminosae- Caesalpinioideae). Mol. Ecol. 7:601-608.

Cardoso SRS, Provan J, Lira CF, Pereira LOR, Ferreira PCG, Cardoso MA (2005) High levels of genetic structuring as a result of population fragmentation in the tropical tree species Caesalpinia echinata Lam. Biodivers. Conserv. 14:1047-1057.

Carvalho PER (1994) Caesalpinia echinata Lamarck. In: Espécies florestais brasileiras. Recomendações silviculturais, potencialidades e uso da madeira. Embrapa - CNPF/SPI, Brasília.

Clark DA, Piper SC, Keeling CD, Clark DB (2003) Tropical rain forest tree growth and atmospheric carbon dynamics linked interannual temperature variation during 1984-2000. Proc. Natl. Acad. Sci. USA 100:5852-5857.

Funari FL (1983) Insolação, radiação solar e radiação líquida no Brasil. São Paulo, University of São Paulo. Master thesis.

Geßler A, Duarte HM, Franco AC, Lüttge U, Mattos EA, Nahm M, Rodrigues PJFP, Scarano FR, Rennenberg H (2005) Ecophysiology of selected tree species in different plant communities at the periphery of the Atlantic Forest of SE - Brazil. III. Three legume trees in a semi-deciduous dry forest. Trees 19:523-530.

Giudice-Neto J Del, Sebbenn AM, Kageyama PY (2005) Diversidade genética de uma população "ex situ" de Caesalpinia echinata Lam. Sci. For. 69:125-133.

Hendrickson L, Ball MC, Wood JT, Chow WS, Furbank RT (2004) Low temperature effects on photosynthesis and growth of grapevine. Plant Cell Environ. 27:795-809.

IBAMA (1992) Instituto Brasileiro do Meio Ambiente e dos Recursos Naturais Renováveis (Brasil). Portaria 37N, de 3 de abril de 1992 (www.ibama.gov.br).

Lafta AM, Lorenzen JH(1995) The effect of high temperature on plant growth and carbohydrate metabolism of potato. Plant Physiol. 109:637-643.

Lewis GP (1998) Caesalpinia. A revision of the PoincianellaErythrostemon group. Royal Botanic Gardens, Kew, London.

Mattson NS, Erwin JE (2005) The impact of photoperiod and irradiance on flowering of several herbaceous ornamentals. Sci. Hort. 104:275-292.
Montagnini F (2001) Strategies for the recovery of degraded ecosystems: experiences from Latin America. Interciencia 26:498-503.

Myster J, Moe R (1995) Effect of diurnal temperature alterations on plant morphology in some greenhouse crops - a mini review. Sci. Hort. 62:205-215.

Paulilo MTS, Felippe GM (1998) Growth of the shrub-tree flora of the Brazilian cerrado: a review. Trop. Ecol. 30:165-174.

Richardson AC, Marsh KB, Bolding HL, Pickering AH, Bulley SM, Frearson NJ, Ferguson AR, Thornber SE, Bolitho KM, Macrae EA (2004) High growing temperatures reduce fruit carbohydrate and vitamin $\mathrm{C}$ in kiwifruit. Plant Cell Environ. 27:423-435.

Robert F, Risser G, Pétel G (1999) Photoperiod and temperature effect on growth of strawberry plant (Fragaria X ananassa Duch.): development of a morphological test to assess the dormancy induction. Sci. Hort. 82:217-226.

Rocha YT (2004) Ibirapitanga: História, distribuição geográfica e conservação do pau-brasil (Caesalpinia echinata Lam., Leguminosae) do descobrimento à atualidade. São Paulo, University of São Paulo. PhD thesis.

Souza RP, Válio IFM (2003) Seedling growth of fifteen Brazilian tropical tree species differing in successional status. Rev. Bras. Bot. 26:35-47.

Souza RP, Montedioca S, Zaidan LBP, Válio IFM (1996) Efeito do fotoperíodo no desenvolvimento inicial de plantas de Mimosa scabrella Benth. Rev. Bras. Bot. 19:41-47.

Stubblebine W, Langenheim JH, Lincoln D (1978) Vegetative response to photoperiod in the tropical leguminous tree Hymenaea courbaril L. Biotropica 10:18-29.

Thomas B, Vince-Prue D (1997) The physiology of photoperiodic floral induction. In: Thomas B, VincePrue D (eds), Photoperiodism in Plants, pp.143-179. Academic Press, San Diego.

Válio IFM (2003) Seedling growth of understorey species of a Southeast Brazilian Tropical Forest. Braz. Arch. Biol. Technol. 46:697-703.

Vaz APA, Figueiredo-Ribeiro RCL, Kerbauy GB (2004) Photoperiod and temperature effects on in vitro growth and flowering of $P$. pusilla, an epiphytic orchid. Plant Physiol. Biochem. 42:411-415.

Zar JH (1999) Biostatistical Analysis. Prentice-Hall Inc., New Jersey.

Zheng SH, Nakamoto H, Yoshikawa K, Furuya T, Fukuyama M (2002) Influence of night temperature on flowering and pod setting in soybean. Plant Prod. Sci. 5:215-218. 